\title{
PERANGKAT PEMBELAJARAN NASKAH DRAMA UNTUK PENINGKATAN KARAKTER NILAI BUDAYA
}

\author{
Asri Musandi Waraulia ${ }^{1}$, Agung Nasrulloh Saputro ${ }^{2}$ \\ Universitas PGRI Madiun ${ }^{1,2}$ \\ Posel: asrimusandi@yahoo.com; goeng_15@yahoo.co.id
}

\begin{abstract}
This study aims to process the development of learning tools drama script oriented on the formation of cultural value characters. This development research refers to the Borg and Gall stage model. The stage consists of ten stages of development, namely the initial research and information collection stage, the planning stage, the initial stage of production format development, the initial test phase, the product revision phase, the field test phase, the product revision phase, the field test phase, the product revision phase end, and dissemination and implementation. In this study only until the final product revision stage without including the phase of dissemination and implementation due to limited time research. This research produced Syllabus, RPP, and textbook of drama script oriented to the formation of character of cultural values. The results of this study can be described that the validation of learning devices assessed by two validators, the language validator and graphic design validator. Validation results indicate that the textbooks are included in either category because the percentage is $\geq 75 \%$, the initial trial results are trialed in limited to seven junior high school students generated by observation data, interview, and student questionnaire. Observation data can be analyzed that the learning of writing drama script with learning device of drama script oriented to the formation of character of cultural value is successful and the class is very active. Based on interview data submitted by the teacher in a positive way, it can be analyzed that the learning of writing drama script with a drama script-oriented learning tools oriented to the formation of cultural value character is successful. Based on the questionnaire data of students who have a positive opinion, it can be analyzed that the learning of writing drama script oriented on the formation of the character of cultural values is successful.

Keywords: development; learning tool; drama script; and cultural values.
\end{abstract}

\begin{abstract}
Abstrak
Penelitian ini bertujuan untuk mengembangan perangkat pembelajaran naskah drama yang berorientasi pada pembentukan karakter nilai budaya. Penelitian pengembangan ini mengacu pada model tahap Borg dan Gall. Tahap ini terdiri dari sepuluh tahap pengembangan, yaitu tahap penelitian awal dan pengumpulan informasi, tahap perencanaan, tahap awal pengembangan format produksi, uji awal, tahap revisi produk, uji lapangan, tahap revisi produk, uji lapangan, akhir revisi produk, dan diseminasi dan implementasi. Dalam penelitian ini hanya sampai tahap revisi produk akhir tanpa termasuk diseminasi dan implementasi karena waktu penelitian terbatas. Penelitian ini menghasilkan Silabus, RPP, dan buku teks naskah drama yang berorientasi pada pembentukan karakter nilai-nilai budaya. Hasil penelitian ini dapat dijelaskan bahwa validasi perangkat pembelajaran dinilai oleh dua validator, validator bahasa dan validator desain grafis. Hasil validasi menunjukkan bahwa buku pelajaran termasuk dalam kategori baik karena persentasenya $\geq 75 \%$, hasil percobaan awal diujicobakan terbatas pada tujuh siswa SMP yang dihasilkan oleh data observasi, wawancara, dan kuesioner siswa. Data observasi dapat dianalisis bahwa pembelajaran menulis naskah drama dengan perangkat pembelajaran naskah drama berorientasi pada pembentukan karakter nilai budaya berhasil dan kelas sangat aktif. Berdasarkan data wawancara yang disampaikan oleh guru secara positif, maka dapat dianalisis bahwa pembelajaran menulis naskah drama dengan alat pembelajaran yang berorientasi pada naskah drama berorientasi pada pembentukan karakter nilai budaya berhasil. Berdasarkan data kuesioner siswa yang memiliki pendapat positif, dapat dianalisis bahwa pembelajaran menulis naskah drama berorientasi pada pembentukan karakter nilai budaya yang berhasil.
\end{abstract}

Kata kunci: pengembangan, perangkat pembelajaran; naskah drama; dan nilai budaya. 


\section{PENDAHULUAN}

Mata pelajaran Bahasa Indonesia di Sekolah Menengah Pertama (SMP) pada dasarnya berfungsi untuk mengembangkan kemampuan bernalar, berkomunikasi, dan mengembangkan pikiran, serta membina persatuan dan kesatuan bangsa. Keberhasilan guru Bahasa Indonesia dalam menjalankan tugasnya sangat dipengaruhi oleh pelaksanaan proses belajar mengajar di dalam kelas. Oleh sebab itu, selayaknya guru bisa siap sedia menyiapkan diri dalam menyajikan bahan belajar, menentukan apa saja yang akan dilaksanakan bersama dengan siswa.

Pengembangan atau pembaruan ini menyentuh sarana non fisik seperti pengembangan kualitas tenaga-tenaga kependidikan yang memiliki pengetahuan, kemampuan, dan keterampilan memanfaatkan fasilitas yang tersedia, serta cara kerja yang inovatif. Pembaruan di bidang pendidikan ini juga menyentuh sarana fisik/fasilitas pendidikan seperti perangkat pembelajaran yang terdiri atas Silabus, Rencana Pelaksanaan Pembelajaran (RPP), dan Buku Ajar.

Penyelenggaraan pengembangan pendidikan salah satunya dilaksanakan dengan cara mengubah dan memberi inovasi pada perangkat pembelajaran yang digunakan di sekolah. Perangkat pembelajaran adalah perangkat yang dipergunakan dalam proses pembelajaran. Perangkat pembelajaran yang diperlukan dalam mengelola proses belajar mengajar dapat berupa: buku siswa, silabus, Rencana Pelaksanaan Pembelajaran (RPP), Lembar Kegiatan Siswa (LKS), Instrumen Evaluasi atau Tes Hasil Belajar (THB), serta media pembelajaran (Ibrahim dalam Trianto, 2010:96).

Inovatif dalam upaya peningkatan mutu pendidikan saat ini belum lengkap jika tidak diimbangi dengan membangun karakter dari peserta didik. Pembentukan karakter siswa ini sangat penting untuk membangun moral bangsa di masa yang akan datang. Pembentukan karakter merupakan sesuatu yang tidak dapat dipisahkan dari kehidupan manusia. Oleh karena itu, lembaga pendidikan khususnya sekolah dipandang sebagai tempat yang strategis untuk membentuk karakter anak. Hal ini dimaksudkan agar peserta didik dalam segala ucapan, sikap, dan perilakunya mencerminkan karakter yang baik dan kuat.

Sejalan dengan tujuan pembelajaran tersebut, perangkat pembelajaran saat ini dikembangkan dengan berorientasi pada pembentukan karakter peserta didik. Perangkat pembelajaran yang berkarakter adalah sarana siswa dan guru agar dapat menghasilkan siswa yang cerdas serta memiliki karakter yang baik. Namun, masalah yang sering timbul adalah perangkat pembelajaran yang disediakan di sekolah belum sesuai dengan kurikulum yang ada serta tidak berbasis pada pendidikan karakter. Beberapa aspek yang belum tampak diantaranya aspek dalam penyajian perangkat pembelajaran serta tingkat kelayakan perangkat pembelajaran, misalnya aspek penyajian perangkat pembelajaran yang berupa buku ajar. Penyajian buku ajar dari sekolah dirasa sangat kaku dan kurang menarik, sehingga siswa malas untuk membaca dan mengerjakan. Selain itu, dari segi kelayakan perangkat pembelajaran, materi dan soal dalam buku ajar tidak berorientasi pada pembentukan karakter siswa dan seringkali tidak mengarah pada tujuan pembelajaran. Penelitian ini menekankan pada pengembangan perangkat pembelajaran, diantaranya silabus, RPP, dan buku ajar. Pengembangan ini bertujuan untuk memperbaiki peranan perangkat pembelajaran baik dari segi isi, kegrafisan, dan penyajiannya yang berorientasi pada pembentukan karakter nilai budaya.

Silabus adalah rencana pembelajaran pada suatu dan/atau kelompok mata pelajaran/tema tertentu yang mencakup standar kompetensi, kompetensi dasar, materi pokok/pembelajaran, 
kegiatan pembelajaran, indikator pencapaian kompetensi untuk penilaian, penilaian, alokasi waktu, dan sumber belajar (Trianto, 2010:96). Rencana Pelaksanaan Pembelajaran (RPP) adalah rencana yang menggambarkan prosedur dan manajemen pembelajaran untuk mencapai suatu kompetensi dasar yang ditetapkan dalam standar isi yang dijabarkan dalam silabus (Trianto, 2010:108).

Selain silabus dan RPP, penelitian ini mengembangkan buku ajar. Buku ajar adalah buku siswa yang digunakan sebagai buku panduan bagi siswa dalam kegiatan pembelajaran, yang memuat materi pembelajaran, kegiatan penyelidikan berdasarkan konsep, kegiatan sains, informasi, contoh-contoh penerapan sains dalam kehidupan sehari-hari (Trianto, 2010: 74).

Penelitian ini menekankan pada pengembangan perangkat pembelajaran aspek menulis, khususnya menulis naskah drama. Hal ini dikarenakan menulis merupakan suatu keterampilan berbahasa yang dipergunakan untuk berkomunikasi secara tidak langsung. Menulis sebagai suatu kegiatan penyampaian pesan (komunikasi) dengan menggunakan bahasa tulis sebagai alat atau medianya (Yunus, 2010: 13). Pesan adalah isi atau muatan yang terkandung dalam suatu tulisan.

Beberapa alasan yang melatarbelakangi penelitian ini adalah arti penting perangkat pembelajaran bagi peserta didik dan guru. Perangkat pembelajaran merupakan pedoman, petunjuk, materi, serta alat evaluasi yang mempunyai peranan penting bagi siswa untuk untuk belajar dan mengembangkan ilmunya serta bagi guru untuk mengarahkan siswanya. Perangkat pembelajaran ini dianggap mempunyai peranan penting untuk mengembangkan aspek kognitif (pengetahuan) siswa, afektif (kepekaan) siswa, sosial, psikomotor, serta mengembangkan karakter berani, kritis, dan kreatif siswa.

Alasan kedua, perangkat pembelajaran ini mengembangkan pada aspek menulis naskah drama dikarenakan menulis merupakan suatu keterampilan berbahasa yang sangat penting bagi siswa. Dengan menulis, siswa dapat berkomunikasi tanpa harus bertemu langsung dengan lawan bicara. Selain itu, siswa juga dapat berkarya lewat tulisan, yakni dengan menulis cerita pendek, novel, puisi, dan naskah drama.

Pengembangan perangkat pembelajaran ini berorientasi pada karakter nilai budaya, karena selain mengembangkan ilmu dan pengetahuan siswa, pendidikan juga dituntut untuk membentuk moral dan karakter siswa yang baik. Pendidikan karakter berbasis nilai budaya, berupa budi pekerti, Pancasila, apresiasi sastra, keteladanan tokoh-tokoh sejarah dan para pemimpin bangsa dan konservasi lingkungan (Khan, 2010: 2).

\section{METODE PENELITIAN}

Penelitian ini merupakan penelitian pengembangan dengan menggunakan kerangka penelitian dari Borg dan Gall dalam Sukmadinata (2006: 169-170) sebagai berikut. 
ISSN (Online): 2621-0851

Volume 1, Nomor 2, November 2018

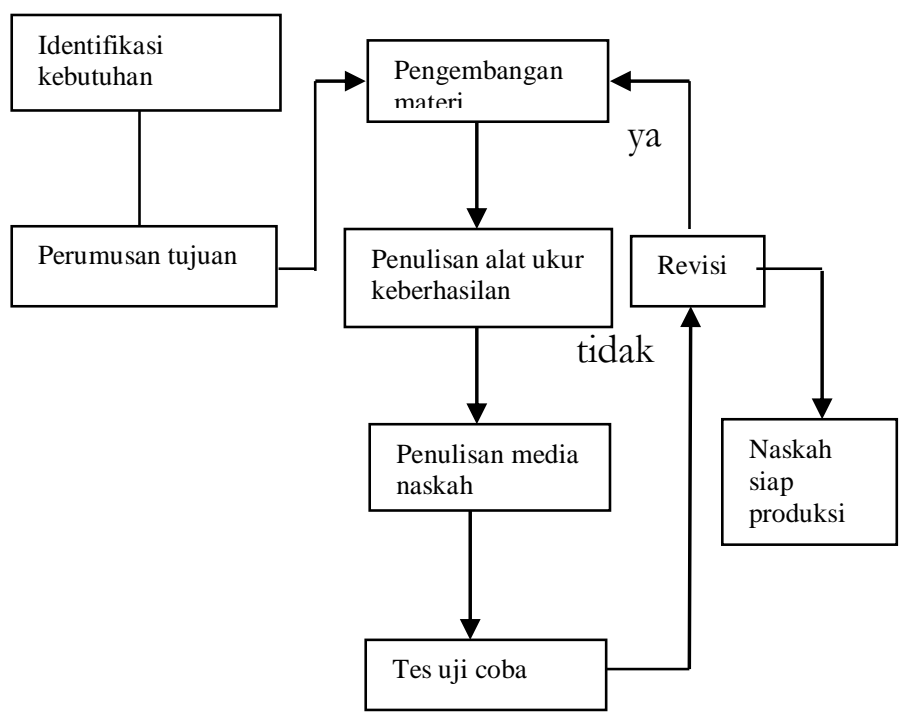

Bagan 1 Model Rancangan Pengembangan Borg dan Gall

Dari bagan di atas dapat dijabarkan sebagai berikut.

1. Penelitian dan pengumpulan informasi awal

Penelitian dan pengumpulan informasi yang meliputi kajian pustaka, pengamatan atau observasi kelas, dan persiapan laporan.

2. Perencanaan

Perencanaan, yang mencakup merumuskan kemampuan, merumuskan tujuan khusus untuk menentukan urutan bahan, dan uji coba skala kecil.

3. Pengembangan format produksi awal

Pengembangan format produksi awal, dalam hal ini adalah penembangan materi.

4. Uji coba awal

Uji coba awal menghasilkan data hasil wawancara, observasi, dan angket yang dikumpulkan dan dianalisis.

5. Revisi produk

Revisi produk, yang dikerjakan berdasarkan hasil uji coba awal. Hasil uji coba tersebut diperoleh informasi kualitatif tentang produk yang dikembangkan.

6. Uji coba lapangan

Uji coba awal ini menghasilkan data kuantitatif dari hasil belajar yang dikumpulkan dan dianalisis sesuai dengan tujuan khusus yang dicapai.

7. Revisi produk

Revisi produk, yang dikerjakan berdasarkan hasil uji coba lapangan. Hasil uji coba lapangan dimaksudkan untuk meningkatkan program atau produk untuk perbaikan pada tahap berikutnya.

8. Uji lapangan

Uji lapangan ini melibatkan subjek penelitian, disertai wawancara, observasi, dan penyampaian angket dan dianalisis. 
9. Revisi produk akhir

Revisi produk akhir, yaitu revisi yang dikerjakan berdasarkan uji coba lapangan.

10. Desiminasi dan implementasi

Desiminasi dan implementasi, yaitu penyampaian hasil pengembangan (proses, prosedur, program, atau produk) kepada para pengguna dan professional melalui forum pertemuan atau menuliskan dalam jurnal, atau dalam bentuk atau handbook.

Karena keterbatasan waktu penelitian, penelitian ini tidak sampai pada desiminasi dan implementasi. Penelitian ini hanya akan menghasilkan revisi produk akhir.

Kriteria perhitungan data dengan menggunakan skala Likert. Kriteria tersebut dapat dijabarkan sebagai berikut.

Tabel 1 Kualifikasi Kelayakan Kualitas Buku Ajar

\begin{tabular}{|l|l|}
\hline Pernyataan & Skala Nilai \\
\hline Sangat berkualitas & 5 \\
berkualitas & 4 \\
Cukup berkualitas & 3 \\
Kurang berkualitas & 2 \\
Tidak berkualitas & 1 \\
\hline
\end{tabular}

(Riduwan, 2003:36)

Dari hasil penilaian dari tabel di atas hasilnya akan dianalisis menggunakan rumus di bawah ini. Jumlah skor hasil validasi

Skor Ideal $=$ Jumlah skor tertinggi

\section{$\mathrm{x} 100 \%$}

Data ini dicocokkan dengan kriteria yang ada sedangkan presentase dari data ini diperoleh berdasarkan perhitungan skala Likert seperti pada tabel 2 berikut.

Tabel 2 Kualifikasi Kualitas Buku Ajar

(Riduwan, 2003: 41)

\begin{tabular}{|l|l|}
\hline Persentase & Kategori \\
\hline $0 \%-20 \%$ & Tidak Berkualitas \\
$21 \%-40 \%$ & Kurang Berkualitas \\
$41 \%-60 \%$ & Cukup Berkualitas \\
$61 \%-80 \%$ & Berkualitas \\
$81 \%-100 \%$ & Sangat Berkualitas \\
\hline
\end{tabular}

\section{HASIL DAN PEMBAHASAN}

\section{Hasil Penelitian}

Penelitian pengembangan ini menggunakan teori Borg dan Gall. Teori ini terdiri atas sepuluh tahap pengembangan, yaitu tahap penelitian dan pengumpulan informasi awal, tahap perencanaan, tahap pengembangan format produksi awal, tahap uji coba awal, tahap revisi produk, tahap uji coba lapangan, tahap revisi produk, tahap uji lapangan, tahap revisi produk akhir, dan desiminasi dan implementasi. Dalam penelitian ini hanya sampai pada tahap revisi produk akhir tanpa menyertakan tahap desiminasi dan implementasi karena keterbatasan waktu penelitian. 
Penelitian dan pengumpulan informasi yang meliputi pengamatan atau observasi kelas. Dalam observasi kelas diperoleh data bahwa karakter nilai budaya (nama tokoh sejarah) siswa telah luntur. Hal ini dibuktian dengan perilaku siswa (Rony Setyawan dan Winda Nur K) saat ditanyai oleh guru tentang nama-nama pahlawan yang telah berjasa terhadap Indonesia, siswa cenderung banyak yang tidak mengenal nama-nama pahlawan tersebut. Berdasarkan hasil pengamatan pada tahap penelitian dan pengumpulan informasi awal ini, peneliti berhasil mengumpulkan informasi awal yang berkaitan dengan gejala-gejala yang mempengaruhi ketidakberhasilan siswa dalam pembelajaran khususnya menulis naskah drama.

Dalam tahap perencanaan ini, peneliti berhasil mengumpulkan data lapangan yang diperoleh dari hasil pengumpulan informasi awal. Hasil pencataan pada tahap penelitian dan pengumpulan informasi inilah yang melandasi peneliti untuk mengembangkan perangkat pembelajaran menulis naskah drama dengan karakter nilai budaya. dalam tahap perencanaan ini pula peneliti melakukan pretest, yang berisi tentang pertanyaan-pertanyaan tentang puisi dan cinta tanah air. Hasil pretest menyebutkan bahwa terdapat 9 siswa yang lulus KKM, yaitu Galuh Lutfi Febritasari, Indatus Fatmawati, Fentika Risqi F, Wahyu Dwi S, Ambar Dwi A, Tutik Triyani, Ciptiningtyas Kensi A, Dina Pangestu, dan Vivi Fridayanti. Selebihnya 21 siswa memperoleh nilai di bawah KKM.

Pengembangan format produksi awal, dalam hal ini adalah pembuatan perangkat pembelajaran menulis naskah drama dengan karakter nilai budaya dan menilaikan silabus, RPP, dan buku ajar kepada dua validator, yaitu validator pembelajaran bahasa Indonesia dan validator desain grafis. Hasil penilaian proses pengembangan buku ajar menulis puisi yang berorientasi cinta tanah air, validator pembelajaran bahasa Indonesia adalah sebagai berikut.

Tabel 3 Data Validasi Pengembangan Format Produksi Awal

\begin{tabular}{|l|l|l|}
\hline \multirow{2}{*}{} & Validator \\
\cline { 2 - 3 } & Ahli Pembelajaran & Ahli Desain Grafis \\
\hline Jumlah Skor hasil Validasi & 50 & 30 \\
\hline Jumlah Aspek Penilaian & 12 & 8 \\
\hline Skor Tertinggi & 5 & 5 \\
\hline
\end{tabular}

1. Analisis Data Validasi Draf 1 Buku Siswa (Validator Ahli Pembelajaran)

$$
\begin{array}{ll}
P & =\quad \frac{\text { Jumlah skor penilaian }}{\text { Jumlah skor tertinggi }} \times 100 \% \\
= & \frac{50}{60} \times 100 \% \\
= & 83,33 \%
\end{array}
$$

2. Analisis Data Validasi Draf 1 Buku Siswa (Validator Ahli Desain Grafis)

$$
\begin{array}{ll}
P & =\frac{\text { Jumlah skor penilaian }}{\text { Jumlah skor tertinggi }} \times 100 \% \\
= & \frac{30}{40} \times 100 \% \\
= & 75 \%
\end{array}
$$


Berdasarkan tabel 3 diketahui bahwa skor validasi pengembangan format produksi awal perangkat pembelajaran menulis naskah drama dengan karakter nilai budaya dari dua validator, yakni ahli pembelajaran bahasa Indonesia dan ahli Desain Grafis, dinilai dalam kategori baik-sangat baik dan layak untuk diujicobakan karena persentasenya $\geq 61 \%$. Selanjutnya untuk mendapatkan kesempurnaan, maka akan dilakukan revisi berdasarkan saran dan komentar dari masing-masing validator, salah satu diantaranya adalah komposisi bentuk lebih variatif dan tidak monoton. Setelah direvisi, maka buku siswa tersebut akan diujicobakan pada tahap uji coba awal.

Uji coba awal menghasilkan data hasil wawancara terhadap guru, observasi oleh pengamat, dan angket siswa yang dikumpulkan dan dianalisis. Uji coba awal diujicobakan kepada tujuh siswa. Hasil wawancara guru dibedakan menjadi tiga yaitu (1) hal-hal yang disukai dari perangkat pembelajaran menulis naskah drama dengan karakter nilai budaya, hasilnya adalah tema yang diangkat cukup relevan, tampilan buku juga menarik, dan materi cukup mendukung proses kreatif, (2) hal-hal yang tidak disukai antara lain, terdapat beberapa penulisan kata yang salah dan penggunaan huruf dan model huruf perlu dibenahi, dan (3) saran untuk perbaikan salah satunya adalah tanpilan font perlu diperbaiki. Dari hasil wawancara terhadap guru tersebut dapat disimpulkan bahwa banyak masukan untuk perbaikan dalam pembuatan perangkat pembelajaran ini dan akan direvisi kemudian akan diujicobakan pada rahap uji coba lapangan. Hasil observasi didominasi penilaian positif yang diberikan oleh pengamat, antara lain siswa memperhatikan penjelasan guru, siswa melaksanakan perintah guru, siswa merespon buku ajar menulis naskah drama dengan karakter nilai budaya, dan siswa dapat menulis naskah drama dengan karakter nilai budaya. Dari beberapa kriteria-kriteria penilain dari wawancara, observasi, dan angket siswa, membuktikan bahwa perangkat pembelajaran ini sudah layak untuk diujicobakan, tetapi juga masih banyak terdapat kesalahan, contohnya kesalahan dalam penulisan kata, untuk itu perlu direvisi dan akan diujicobakan kembali pada tahap uji coba lapangan.

Uji coba awal ini menghasilkan data kuantitatif dari hasil belajar yang dikumpulkan dan dianalisis sesuai dengan tujuan khusus yang dicapai. Uji coba lapangan diujicobakan kepada 10 siswa, yang berbeda dengan awal. Data kuantitatif diperoleh hasil penilaian menulis naskah drama. Kriteria penilaian didasarkan pada teori Nurgiantoro (2010: 487). Hasil nilai siswa adalah sebagai berikut.

Tabel 4 Hasil Nilai Siswa

\begin{tabular}{|c|c|c|}
\hline $\mathrm{No}$ & Nama & Nilai \\
\hline 1. & Retno Inten & 76 \\
\hline 2. & Sabdo Ibrahim & 80 \\
\hline 3. & Herlina Oktaviani & 88 \\
\hline 4. & Anggi P & 76 \\
\hline 5. & Dwi Astuti & 80 \\
\hline 6. & Lilik Suntari & 76 \\
\hline 7. & Ayu Nova & 80 \\
\hline 8. & Tria Arifin & 80 \\
\hline 9. & Yuli Tri Anna & 80 \\
\hline 10. & Dwi Ratnawati & 76 \\
\hline \multicolumn{2}{|c|}{ Jumlah } & 792 \\
\hline & Rata-rata & 79,2 \\
\hline
\end{tabular}


ISSN (Online): 2621-0851

Volume 1, Nomor 2, November 2018

a. Persentase Kategori Nilai Siswa Tahap Uji Coba Lapangan

Persentase setiap kategori nilai siswa dihitung dengan membagikan frekuensi nilai siswa setiap kategori dengan jumlah keseluruhan siswa dikalikan seratus persen. Persentase setiap kategori nilai siswa dihitung untuk mengetahui berapa persen siswa yang mendapatkan nilai tertentu, sehingga dapat diketahui hasil dari pembelajaran menulis naskah drama dengan menggunakan buku ajar menulis naskah drama dengan karakter nilai budaya, yaitu naskah drama siswa. Perhitungannya sebagai berikut.

Tabel 5 Distribusi Persentase Kategori Nilai Sisw
\begin{tabular}{|l|l|l|}
\hline Nilai & Frekuensi & Persentase \\
$(X)$ & $(f)$ & $(P)$ \\
\hline $89-91$ & 0 & $0 \%$ \\
$86-88$ & 1 & $10 \%$ \\
$83-85$ & 0 & $0 \%$ \\
$80-82$ & 5 & $50 \%$ \\
$77-79$ & 0 & $0 \%$ \\
$74-76$ & 4 & $40 \%$ \\
$71-73$ & 0 & $0 \%$ \\
$68-70$ & 0 & $0 \%$ \\
$65-67$ & 0 & $0 \%$ \\
\hline Total & $10=\mathrm{N}$ & $100 \%=\sum \mathrm{P}$ \\
\hline
\end{tabular}

Berdasarkan hasil perhitungan (Tabel 5), dapat dijelaskan bahwa persentase kategori nilai siswa pada hasil perlatihan siswa, yakni menulis naskah drama, kategori nilai tertinggi, yakni antara 86--88 hanya diperoleh oleh seorang siswa dengan nilai 88 dengan persentase 10\%. Kategori nilai antara 80-82 diperoleh 50\% dari keseluruhan jumlah siswa. Sedangkan kategori nilai menulis puisi yang paling rendah terletak pada nilai antara 74-76 dengan persentase 40\%. Jadi dapat disimpulkan bahwa pada tahap uji coba lapangan pada pembelajaran menulis naskah drama dengan karakter nilai budaya dikatakan berhasil karena nilai siswa berada di atas KKM yaitu 75 .

b. Rata-rata Nilai Siswa pada Uji Coba Lapangan

Rata-rata nilai siswa pada tahap uji coba lapangan dihitung dengan menjumlah hasil perkalian antara nilai tengah (midpoint) dari masing-masing interval dan frekuensinya dibagi dengan jumlah keseluruhan siswa dikalikan seratus persen. Persentase rata-rata nilai siswa dihitung untuk mengetahui rata-rata hasil belajar siswa saat pembelajaran menulis naskah drama dengan karakter nilai budaya. Perhitungan rata-rata nilai kelas sebagai berikut. 
Tabel 6 Perhitungan Rata-Rata (Mean) Nilai Siswa

\begin{tabular}{|l|l|l|l|}
\hline Interval Nilai & $\begin{array}{l}\text { Frekuensi } \\
(f)\end{array}$ & $\begin{array}{l}\text { Nilai Tengah } \\
(X)\end{array}$ & $f X$ \\
\hline $89-91$ & 0 & 90 & 0 \\
$86-88$ & 1 & 87 & 87 \\
$83-85$ & 0 & 84 & 0 \\
$80-82$ & 5 & 81 & 405 \\
$77-79$ & 0 & 78 & 0 \\
$74-76$ & 4 & 75 & 300 \\
$71-73$ & 0 & 72 & 0 \\
$68-70$ & 0 & 69 & 0 \\
$65-67$ & 0 & 66 & 0 \\
\hline Total & $10=\mathrm{N}$ & - & $792=\sum \mathrm{fX}$ \\
\hline
\end{tabular}

Dari tabel 6 diperoleh $\sum \mathrm{fX}=792$, dan $\mathrm{N}=10$, dengan demikian rata-rata (Mean) nilai siswa kelas $\mathrm{X}$ dapat dihitung, sebagai berikut.

$$
\begin{aligned}
\mathrm{M}_{\mathrm{x}} & =\sum \frac{f X}{N} \\
\mathrm{M}_{\mathrm{x}} & =\frac{792}{10} \\
\mathrm{M}_{\mathrm{x}} & =79,2
\end{aligned}
$$

Dari hasil perhitungan mean di atas, hasil/nilai rata-rata kelas pada pembelajaran menulis naskah drama menggunakan perangkat pembelajaran menulis naskah drama dengan karakter nilai budaya adalah 79,2. Jadi dapat ditarik simpulan bahwa hasil belajar bidang studi bahasa Indonesia kompetensi dasar menulis naskah drama dengan karakter nilai budaya dianggap berhasil dengan baik menurut pendeskripsian modifikasi skala likert karena rata-rata nilai kelas terletak pada skala interval 61-80.

Uji lapangan ini menghasilkan data wawancara dengan guru, observasi oleh pengamat, dan penyampaian angket siswa. Uji coba lapangan diujicobakan kepada 15 siswa yang berbeda dengan tahap uji coba sebelumnya.Hasil wawancara dengan guru cenderung ke dalam hal positif, hal ini dibuktikan dalam turunnya hal-hal yang tidak disukai, yaitu 2 hal yang tidak disukai menjadi 1 hal yang tidak disukai dari buku ajar menulis naskah drama dengan karakter nilai budaya. Walaupun demikian tetapi buku ajar ini masih perlu adanya perbaikan dari segi kesalahan kata. Hasil observasi oleh pengamat didominasi pada hal-hal positif, tetapi terdapat beberapa kegiatan siswa yang cenderung negatif seperti masih gaduh di pada saat pelajaran berlangsung. Hasil penyampaian angket siswa menyebutkan bahwa siswa banyak memberikan pandangan positif terhadap buku ajar menulis naskah drama dengan karakter nilai budaya, seperti yang dikemukakan oleh Aprilian Tri W bahwa buku ajar ini isinya lengkap, kata-katanya menarik, mudah dimengerti, isinya menarik untuk dibaca, dan dilengkapi dengan evaluasi. Dari beberapa hal positif tersebut terdapat hal negatif seperti yang dikemukakan oleh Anggi Purtika W bahwa buku ajar ini banyak sekali kesalahan dalam penulisan dan halaman judul kurang menarik. Dari hasil uji lapangan tersebut, buku ajar menulis naskah drama 
dengan karakter nilai budaya masih perlu perbaikan, sebelum diberikan kepada siswa. Dengan demikian setelah direvisi buku ini layak sebagai buku ajar siswa. Berdasarkan hasil analis data dalam proses pengembangan, dapat disimpulkan bahwa perangkat pembelajaran menulis naskah drama dengan karakter nilai budaya ini layak untuk diajarkan kepada siswa.

\section{Pembahasan}

Dalam pengembangan perangkat pembelajaran menulis naskah drama dengan karakter nilai budaya ini langkah Borg dan Gall ini sejalan dengan apa yang dikemukakan oleh Kemp (1994: 84) yang mengatakan bahwa materi atau bahan ajar merupakan gabungan antara pengetahuan yang termasuk di dalamnya fakta dan informasi, keterampilan yang mencakup langkah, prosedur, keadaan, syarat, dan faktor sikap (knowlegde, skill, dan attitude). Di dalam buku ajar menulis puisi ini, peneliti telah memasukkan ketiga aspek tersebut, yaitu knowledge, skill, dan attitude.

Selain itu, silabus, RPP, dan buku ajar ini juga bermanfaat sebagai bahan bacaan siswa yang juga sebagai panduan belajar, baik dalam proses pembelajaran di kelas maupun belajar mandiri. Materi ajar berisikan garis besar bab, kata-kata sains yang dapat dibaca pada uraian materi pelajaran, tujuan yang memuat tujuan yang hendak dicapai setelah mempelajari materi ajar, materi pelajaran berisi uraian materi yang harus dipelajari, bagan atau gambar yang mendukung ilustrasi pada uraian materi, kegiatan percobaan menggunakan alat dan bahan sederhana dengan teknologi sederhana yang dapat dikerjakan oleh siswa, uji diri setiap submateri pokok, dan masalah-masalah dalam kehidupan sehari-hari yang perlu didiskusikan (Trianto, 2010: 113).

\section{SIMPULAN}

Berdasarkan hasil penelitian dapat diambil simpulan bahwa validasi perangkat pembelajaran dinilai oleh dua validator, yaitu validator kebahasaan dan validator desain grafis. Hasil validasi menunjukkan bahwa buku ajar termasuk dalam kategori baik karena persentase $\geq 75 \%$, hasil uji coba awal diujicobakan secara terbatas pada tujuh siswa SMP dihasilkan data observasi, wawancara, dan angket siswa. Data observasi dapat dianalisis bahwa pembelajaran menulis naskah drama dengan perangkat pembelajaran naskah drama berorientasi pada pembentukan karakter nilai budaya ini berhasil dan kelas sangat aktif. Berdasarkan data wawancara yang disampaikan oleh guru secara positif, maka dapat dianalisis bahwa pembelajaran menulis naskah drama dengan perangkat pembelajaran naskah drama berorientasi pada pembentukan karakter nilai budaya ini berhasil. Berdasarkan data angket siswa yang memiliki pendapat positif, maka dapat dianalisis bahwa pembelajaran menulis naskah drama berorientasi pada pembentukan karakter nilai budaya ini berhasil proses pengembangan perangkat pembelajaran menulis naskah drama dengan karakter nilai budaya yang dikembangkan sudah layak dan memenuhi syarat untuk digunakan sebagai buku ajar menulis naskah drama.

\section{DAFTAR PUSTAKA}

Kemp, Jerrold. E. 1994. Proses Perancangan Pengajaran. Bandung: ITB.

Khan, Yahya. 2010. Pendidikan Karakter Berbasis Potensi Diri. Yogyakarta: Pelangi Publishing.

Nurgiantoro, Burhan. 2010. Penilaian Pembelajaran Bahasa. Yogyakarta: BPFE. 
SeBaSa: Jurnal Pendidikan Bahasa dan Sastra Indonesia

Riduwan. 2003. Dasar-dasar Statistika. Bandung: ALFABETA.

Sukmadinata, Nana Syaodih. 2006. Metode Penelitian Pendidikan. Bandung: Remaja Rosida Karya.

Trianto. 2010. Model Pembelajaran Terpadu: Konsep, Strategi, dan Implementasinya dalam Kurikulum Tingkat Satuan Pendidikan (KTSP). Jakarta: Bumi Aksara.

Yunus, Suparno Mohamad. 2010. Keterampilan Dasar Menulis. Universitas Terbuka. 